\title{
DEMONSTRATION OF A MULTIPLE DRIFT NET FOR AQUATIC ORGANISMS
}

\author{
Michael D. Porter ${ }^{1 *}$, Seth Kennedy², Juddson Sechrist ${ }^{3}$
}

${ }^{1}$ U.S. Army Corps of Engineers, Albuquerque District, 4101 Jefferson Plaza NE, Albuquerque, NM 87109 USA

${ }^{2}$ Northwind, Arvada, CO 80003 USA

${ }^{3}$ U.S. Bureau of Reclamation, Columbia Pacific Northwest Regional Office, 1150 N. Curtis Rd, Boise, ID 83706 USA

*Corresponding Author: michael.d.porter@usace.army.mil

\section{ARTICLE INFO}

Received: 19 October 2020

Accepted: 12 January 2021

\section{Keywords:}

Pelagic-broadcast spawning fish

Egg drift

Rio Grande Silvery Minnow

Hybognathus amarus

\section{ABSTRACT}

The distribution of drifting semi-buoyant fish eggs within a river is useful for understanding the ecology of pelagic-broadcast spawning fish. The vertical position of semi-buoyant eggs in the water column is an important parameter describing transport processes for these species. We designed a multiple drift net (five rectangular nets attached to a frame) to vertically divide the water column into stacked horizontal layers to sample drifting semi-buoyant particles. We deployed the multiple drift net gear beside Moore egg collectors in a wadeable channel to sample the vertical distribution of semi-buoyant polyacrylamide gel beads as surrogates for fish eggs in the water column. The vertical distribution of beads was predominantly found in the deeper nets of the multiple drift net gear while the surface nets and Moore egg collectors had fewer beads which is similar to the results in other studies of pelagic-broadcast spawning fish. The multiple drift net gear is a tool that demonstrates the capability to sample the water column under variable flow conditions (depth, velocity and turbulence) for field data on the vertical distribution of drifting eggs (or surrogates). These empirical data can quantify drift patterns of eggs for modeling transport and retention in pelagic-broadcast spawning species.

Porter, M. D., Kennedy, S., Sechrist, J. (2021): Demonstration of a multiple drift net for aquatic organisms. Croatian Journal of Fisheries, 79, 25-32. DOI: $10.2478 /$ cjf-2021-0003. 


\section{INTRODUCTION}

Worthington et al., (2017) reviewed the general life history of the pelagic-broadcast spawning (PBS) minnow guild (17 species, Family Leuciscidae) based on non-adhesive semibuoyant eggs that drift downstream during incubation. The mechanisms of egg drift and early life history vary within the guild (Dudley and Platania, 2007; Medley et al., 2007; Widmer et al., 2010; Medley and Shirey, 2013; Chase et al., 2015; Worthington et al., 2017; Valdez et al., 2019). Surrogates for PBS fish eggs including gellan beads (Reinert et al., 2004; Fluder et al., 2007; Medley et al., 2007; Widmer et al., 2010; Worthington, 2013a, 2013b) and nylon beads (Dudley and Platania, 1999, 2007), have proved useful for studying egg transport and retention mechanisms. The similarities in shape and specific gravity of surrogates with the eggs of PBS species provide information on downstream egg transport velocity and distance (Dudley and Platania, 2007), retention on the floodplain (Fluder et al., 2007) or in-channel retention (Medley et al., 2007; Widmer et al., 2010). The assumption that drifting PBS eggs and surrogates are randomly or uniformly distributed throughout the water column is a reasonable approach in the absence of a sampler capable of collecting vertically distributed eggs and particles in the water column. The changing vertical distribution of gellan beads in a flume as a function of water volume, velocity, and distance from the source (Worthington et al., 2013a) suggests that collecting drifting eggs over the range of water depths may be useful to understand the mechanics and early life history of PBS species.

Rio Grande Silvery Minnow (Hybognathus amarus Girard) spawning coincides with the rising spring hydrograph (Pease et al., 2006; Widmer et al., 2010; Dudley et al., 2018). Their eggs rapidly expand to a mean diameter greater than $3.0 \mathrm{~mm}$, and have a specific gravity ranging from 1.0019 to 1.0050 at salinities of 0-4 ppt (Alleman, 2008; Cowley et al., 2009). Rio Grande Silvery Minnow egg distribution (Porter and Massong, 2004; Widmer et al., 2010) and abundance studies (Dudley et al., 2018) in the Middle Rio Grande in New Mexico typically used Moore egg collectors (MEC; Altenbach et al., 2000) to sample below the water surface ( 0.33 $\mathrm{m}$ depth) for drifting eggs or organisms (Altenbach et al., 2000; Worthington et al., 2013a, 2013b). Worthington et al., (2013a) describe the vertical distribution of semi-buoyant beads as a function of water volume, with lower velocities skewing the distribution toward the lower water column. A potential consequence of this phenomena, and by extension with near-surface sampling, is lower detection as channel depth increases. Field observations of semi-buoyant beads indicate their location in the water column can be affected by water velocity and channel morphology (Porter and Massong, 2004, Worthington et al., 2013b). Physiological changes to the egg (Cowley et al., 2009), and comparatively low capture rates from other studies indicate the value for describing the vertical distribution of eggs (e.g., Widmer et al., 2010; Worthington et al., 2013a, b).

The multiple drift net (MDN) was developed as a single gear to consistently sample vertically distinct layers within the riverine water column for PBS fish eggs. The MDN gear has rectangular net openings (Figure 1) that divide the water column into several adjacent compartments that enables comparison of concurrent samples from the total water column. This gear configuration is not affected by confounding problems including differences in sampling time, turbidity, or other environmental effects to drift conditions if nets are set sequentially at different depths. The capability to collect vertically distributed particles supports comparisons of surrogates with eggs under changing water velocities and flow patterns (turbulence). Our study objectives are to demonstrate how the MDN gear samples the entire water column of a wadeable stream (0.00-1.00 $\mathrm{m}$ depth) from the surface to the bottom boundary layers in comparison to the MEC, and illustrate with semi-buoyant beads how drifting PBS eggs may become vertically distributed in the water column.

\section{MATERIAL AND METHODS}

The Low Flow Conveyance Channel is a narrow channel constructed by the U.S. Bureau of Reclamation during the 1950s. The channel flows parallel to the Rio Grande between San Acacia Diversion Dam and Elephant Butte Reservoir to reduce water loss due to evaporation and transpiration. The channel near San Marcial, New Mexico $\left(33^{\circ} 36^{\prime} 41.50^{\prime \prime} \mathrm{N}, \quad 107^{\circ} 1^{\prime} 6.15^{\prime \prime} \mathrm{W}\right.$ by $33^{\circ} 36^{\prime} 40.95^{\prime \prime} \mathrm{N}$, $107^{\circ} 11^{\prime} 5.55 \mathrm{~W}$ ) was selected as a study site for comparing the two gear types. This location provides sufficient depth (0.0-1.0 m) to submerge the MDN gear with stable flow conditions that minimized turbulence and variation in water velocities for this study.

The MDN gear consists of a vertical column of five individual plankton nets (Figure 1), suspended in the water column by a tubular metal frame fastened to two steel posts driven into the stream bed. Each rectangular net opening measures $0.50 \mathrm{~m}$ wide $\times 0.20 \mathrm{~m}$ deep (mouth sampling area of $0.10 \mathrm{~m}^{2}$ ), with $0.1-\mathrm{mm}$ mesh and net length of $1.5 \mathrm{~m}$. For analysis purposes the five nets of the MDN gear were labeled $A$ through $E$, with $A$ being the top net (surface) and $E$ being the bottom net. Metal battens inserted into sleeves on the top and bottom of each net were attached to the frame to hold the nets open in the water column. Plankton sample bottles were attached to the cod-end of each net to collect the samples. Sample bottle contents were emptied into separate labeled jars at the end of each sampling period for subsequent enumeration in the lab. The MEC is a sluice-box-like gear (see Altenbach et al., 2000; Worthington et al., 2013a for design characteristics) with a $0.45 \mathrm{~m} \times 0.33 \mathrm{~m}$ rectangular opening at its upstream end (sampling area 


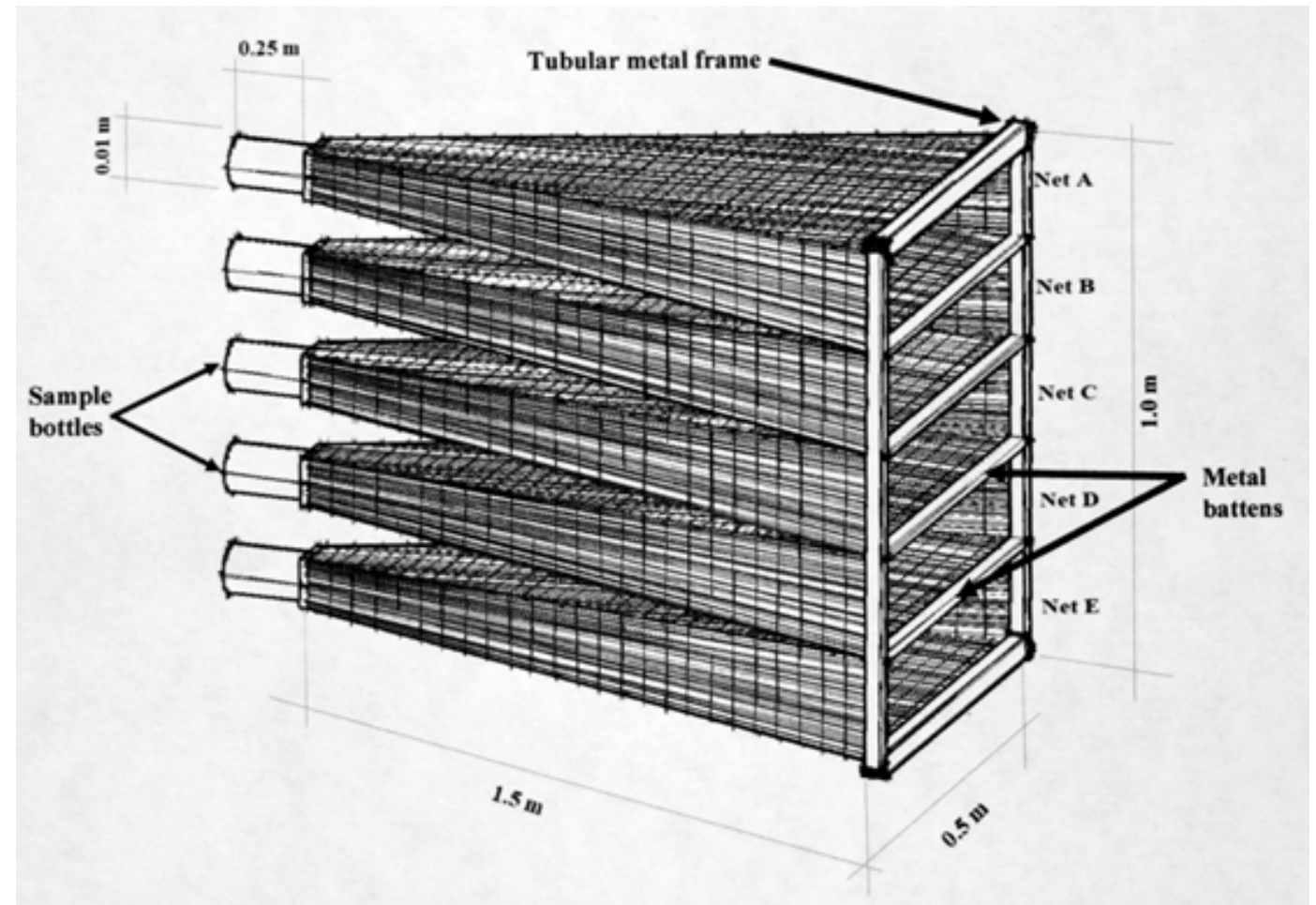

Fig 1. Isometric view of the multiple drift net with nomenclature. The $4.4 \mathrm{~cm}$ diameter tubular frame is a commercially available galvanized chain link fence metal gate frame. The metal battens are cut to the frame width from chain link fence tension bars. The individual plankton nets are $1.50 \mathrm{~m}$ in length with a mesh size of $0.1 \mathrm{~mm}$. Each net has an opening of $0.50 \mathrm{~m}$ wide $\times 0.20 \mathrm{~m}$ height with sleeves along the upper and lower edges. Metal battens inserted in the sleeves are attached to the frame using tension bands. The $10.0 \mathrm{~cm} \times 25.0 \mathrm{~cm}$ sample bottles are attached to a collar on the cod-end of each net.

of $0.15 \mathrm{~m}^{2}$ ), parallel $1.19-\mathrm{m}$ sides, and an open top. The bottom is a framed fiberglass window screen of $1.6-\mathrm{mm}$ mesh. Materials were transferred from the screens to labeled sample jars throughout each sampling period for enumeration in the lab. Two MDNs and two MECs (Figure 2) were deployed side-by-side at the site for each trial. A velocity and depth measurement were recorded in front of each gear on seven sampling occasions using a MarshMcBirney velocity meter (Hach Company, Loveland, $\mathrm{CO}$ ) and a stadia rod at 0.60 water column depth (U.S. Geological Survey, 1982) to document average watercolumn velocity.

Egg surrogates used to standardize target density in flows (Worthington et al., 2013a, 2013b) were released $25 \mathrm{~m}$ upstream of the samplers to ensure constant target availability for each gear type. Commercial polyacrylamide gel beads (beads; Floral Supply, Seeley Lake, Montana) were used as surrogates. The semi-buoyant beads $(6.0$ $\mathrm{mm}$ diameter, specific gravity 1.02-1.43 in tap water) have similar properties to fish eggs (Dudley and Platania, 1999). The beads were released from a vertical slotted tube $25 \mathrm{~m}$ upstream of the midpoint between the samplers for an initially uniform vertical distribution throughout the water column for each trial (Figure 3). The internal vertical slotted tube was constructed from one piece of PVC tubing $(1.30 \mathrm{~m}$ tall with a diameter of $3.8 \mathrm{~cm})$ and was placed inside the larger external tube $(1.20 \mathrm{~m}$ tall with a diameter of $4.5 \mathrm{~cm}$ ) and sealed on the bottom with a 4.5 cm cap.

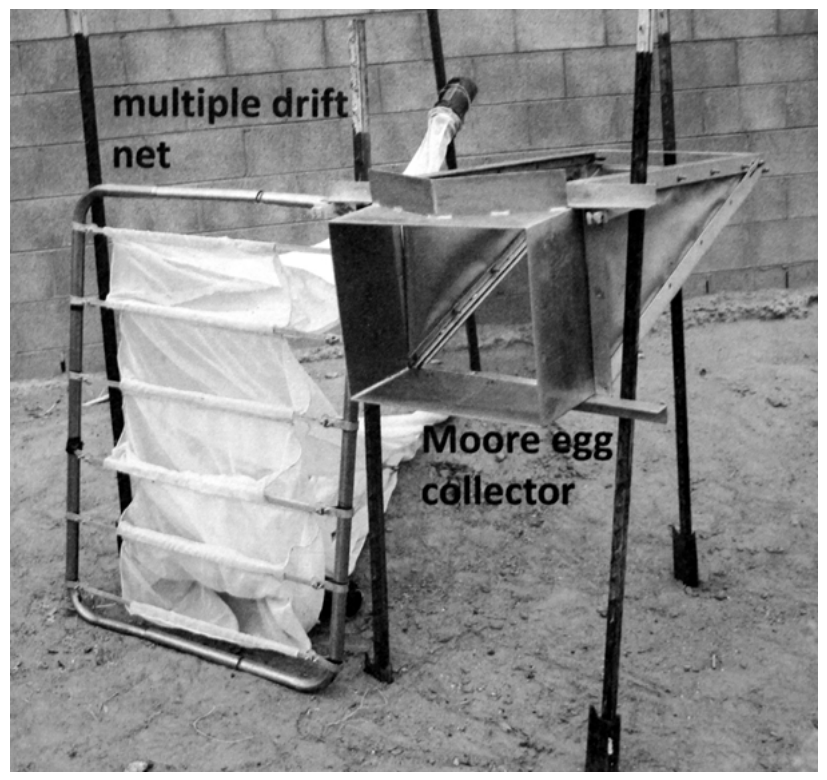

Fig 2. The multiple drift net (left) beside a Moore egg collector (right) mounted on posts to demonstrate the normally submerged equipment 

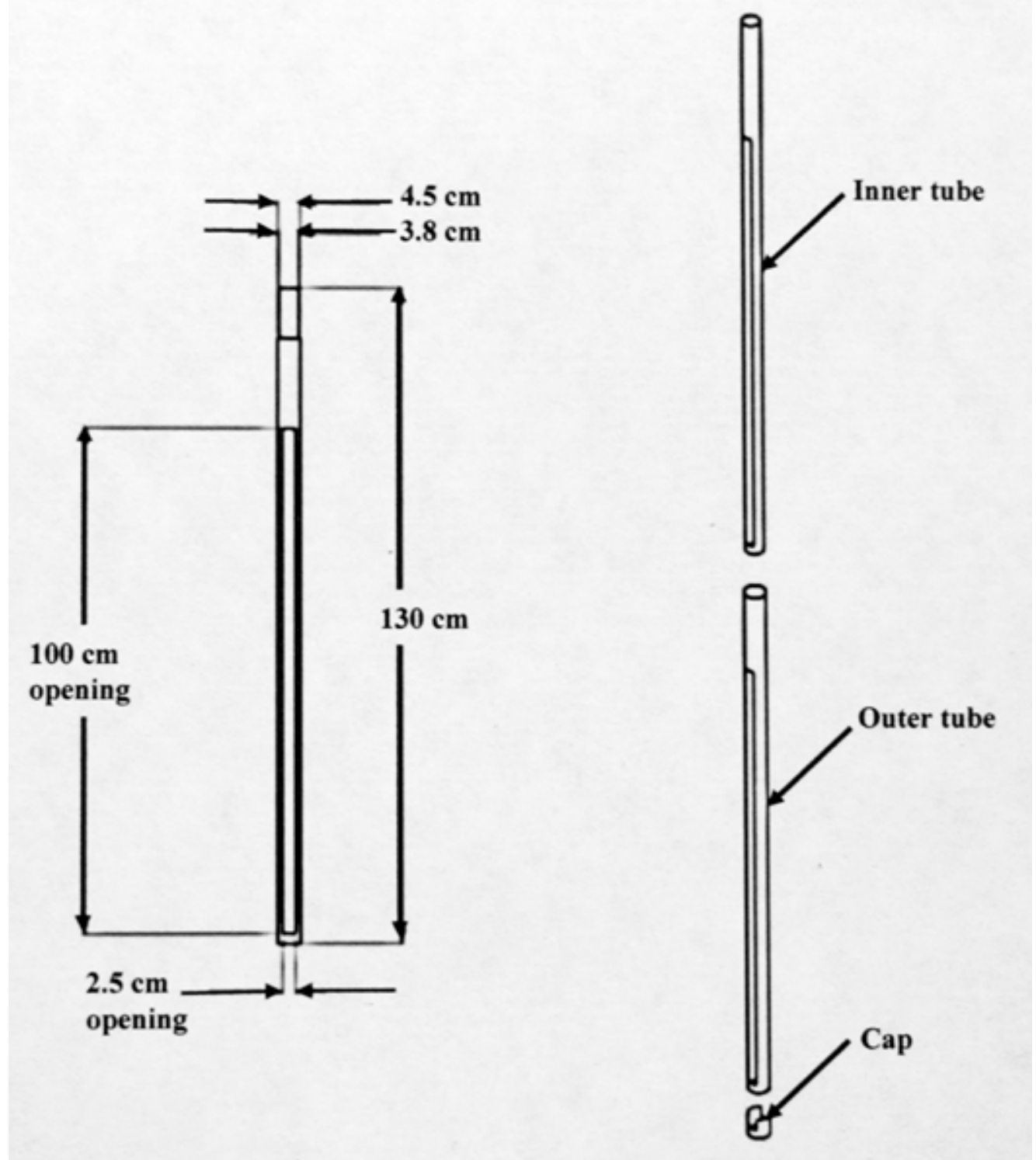

Fig 3. Plan (A) and isometric (B) view of release tube. The release tube is constructed from two slotted PVC tubes one inside the other. The internal tube was one piece of PVC tubing $(1.30 \mathrm{~m}$ tall with a diameter of $3.8 \mathrm{~cm})$ was placed inside the larger external tube $(1.20 \mathrm{~m}$ tall with a diameter of $4.5 \mathrm{~cm})$ and sealed on the bottom with a $4.5 \mathrm{~cm}$ cap. Each tube had a $2.5 \mathrm{~cm}$ wide $\times 1.00 \mathrm{~m}$ length slot on opposite sides of the both tubes. The internal tube slot is aligned $90^{\circ}$ to the external tube slot for filling the internal tube with beads the full vertical height of the water column. Turning the inside tube slots $90^{\circ}$ to parallel with the external tube allows flow through the openings to release the beads with an initial uniform vertical distribution in the water column

Each tube had a $2.5-\mathrm{cm}$ opening on opposite sides of the tube to allow flow through the tubes. Turning the inside tube slot $90^{\circ}$ to the outside tube closes the flow through both openings. The inside tube holds 4000 beads that filled the tube to the $1 \mathrm{~m}$ depth of the water column at the release site. Turning the inside tube back $90^{\circ}$ aligns the openings of both tubes with the flow releasing a simultaneous and uniform distribution of beads into the water column (Figure 3).

The study using the MEC and the MDN was conducted over two days (August 25-26, 2010) with seven trials (Day
1) and eight trials (Day 2). The trial sampling periods were based on anticipated durations for field sampling. The 30 min duration sampling periods started with the bead release $25 \mathrm{~m}$ upstream of the sampling gear, and ended with removal of the gear from the water. Initially, 4000 beads were released per trial (1-5); this was increased to 8000 beads per sample for the remaining ten trials in order to increase the number of beads collected by the gear. The collected sample materials were drained and separated from any sediment and the number of beads enumerated. 
The influence of gear type and sampling depth on the mean number of beads collected per 1000 released was evaluated using a two-way analysis of variance (ANOVA) implemented in the statistical package $R$ v. 3.4.1 ( $R$ Project, 2019). Paired combinations of all nets (MEC, MDN nets A-E) were compared using Tukey's Honest Significant Difference test on the ANOVA results.

\section{RESULTS}

During the trials the total depth was $1.22 \pm 0.07 \mathrm{~m}$ and mean water velocity was $0.429 \pm 0.025 \mathrm{~m} / \mathrm{s}$. The mean number of beads collected per 1000 released varied by depth (Figure 4), with the number of beads collected decreasing with elevation above the substrate $\left(F_{2,177}=120.360, P<\right.$ $0.001)$. The lowest mean number of beads per 1000 were collected at the water surface $(0.90 \mathrm{~m}$ elevation above the substrate) in net $A$ (mean $=0.138 \pm 0.24)$, followed by the MEC $(0.84 \mathrm{~m}$ elevation; mean $=0.475 \pm 0.91)$. Higher number of beads per 1000 were collected lower in the water column in nets $D($ mean $=4.746 \pm 4.08)$ and $E$ (mean $=6.192 \pm 4.27)$. The larger total sample area $\left(0.50 \mathrm{~m}^{2}\right)$ of the MDN gear (nets A-E) collected a larger number of beads per 1000 (mean=15.5 \pm 11.1 ). Pairwise comparisons with the Tukey HSD indicate there were no differences in the mean number of beads per 1000 released among the MEC, MDN-A, and MDN-B samples in the upper water column (depth $0.00-0.40 \mathrm{~m}$ ).

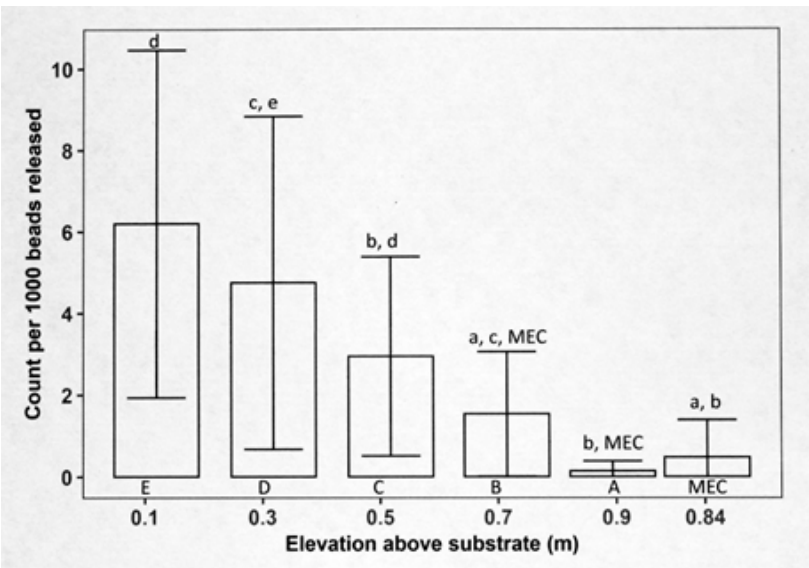

Fig 4. Mean and standard deviation count of beads per 1000 released at a total depth of $1.22 \pm 10.07 \mathrm{~m}$ and water velocity of $0.429 \pm 0.025 \mathrm{~m} / \mathrm{s}$. The nets run from deepest (left) to shallowest (right). The $x$-axis is the approximate elevation $(m)$ above the substrate for the center of each net opening. The A-E nets had a mouth area of $0.10 \mathrm{~m}^{2}$ while the MEC had a mouth area of $0.15 \mathrm{~m}^{2}$. The letters above the bars identify nets that were similar in the Tukey HSD test. The standard deviation negative lower limits for MDN net $A$ and the MEC were set to 0.0

\section{DISCUSSION}

Empirical data collection of the water column using MDN gear produces a vertical particle distribution (Worthington, 2013a) resulting from the local interaction of egg properties and flowing water properties (Medley and Shirey, 2013). Documenting the vertical egg surrogates distribution supports deploying several MDN gear along a channel cross-section to examine the lateral distribution of particles in the current, and the longitudinal distribution of particles within the current as a function of dispersal over time. One priority for future testing is model-based research trials where depth and velocity can be controlled (Worthington et al., 2013a). The MDN gear is an adaptable tool designed to increase the vertical sample range of water column depth $(1.0+\mathrm{m})$ deeper than the MEC $(0.33$ $\mathrm{m})$. The MDN's tubular box frame can be lengthened to increase the number of nets, sample in deeper water, or to sample at specific depths, and provides versatility for deployment in various environments. The MDN frame can be anchored on the bottom in deep water to sample the benthic zone, attached to pontoons to sample at the water surface, or suspended at other levels within the water column. The MEC is superior for sampling at the water surface in wadeable rivers due to its capability for continual removal of fish eggs and debris. The MEC is also well-suited for collecting Rio Grande Silvery Minnow eggs at lower, shallow flows during spring runoff for transfer into hatcheries.

Egg settling in the water column as a function of several biological and environmental parameters determines the conditions which eggs are likely to be sampled by a gear (Dudley and Platania, 1999; Cowley et al., 2009; Garcia et al., 2013). Neutrally buoyant particles with a specific gravity $=1.0$ should either have a random or uniform vertical distribution in the water column. However, the increasing water velocity at the surface would increase the water volume sampled and the number of particles collected. The predicted particle distribution within each MDN net should be a function of the volume of water sampled. Positively buoyant particles with a specific gravity $<1.0$ should occur only in the upper water column regardless of total depth sampled, and the converse is semi-buoyant particles with a specific gravity $>1.0$ should occur closer to the substrate (Cowley et al., 2009; Garcia et al., 2013). The distribution of semi-buoyant fish eggs in the water column varies with water velocity and depth (Garcia et al., 2013). Calculating the total of neutrally or positively buoyant particles in the water column based on sampling the upper water column with the MEC, MDN-A, and MDN-B would overestimate the number. The MEC samples the upper water column $(0.33 \mathrm{~m}$ below water's surface) which may limit its effectiveness for collection when eggs occur deeper in the water column (closer to the substrate). Consequently, the use of surface samplers such as MEC are likely to underestimate the number of 
drifting PBS eggs as depth increases at sample locations. This assertion could be verified by further field trial, especially since there are limitations to extrapolating catch results from a single sampler (see Brittain and Eikeland, 1988) or from samplers with fixed depth (this study) to the whole cross-section of a stream.

The detailed distribution data generated by the MDN would improve analysis for estimating particle drift and retention (Garcia et al., 2013; Garcia et al., 2015; Widmer et al., 2010). The interaction of eggs in flowing water leading to displacement versus retention provides important insights into PBS fish life history (Medley and Shirey 2013; Worthington et al., 2017). Worthington et al., (2013a) demonstrated the effects that water volume, velocity and turbulence have on shifting the distribution of the particles toward the surface. The FluEgg model (Garcia et al., 2013, 2015) estimates semi-buoyant egg density as a function of egg age, diameter, and density interacting with water density to simulate egg diffusion along longitudinal, lateral, and vertical flow axes. The results from this study present a hypothetical distribution for comparison with uniform and random distributions of fish eggs under variable river flow conditions. The velocity of drifting gel beads at the water-substrate boundary layer was not evaluated. Beads closer to the water surface (above average water velocity) are likely transported downstream faster than beads near the substrate in slower than average velocity water (see U.S. Geological Survey, 1982). Shorter consecutive sample intervals (5-10 minutes) producing a temporal depletion sample would better document the particle transport velocity as a function of vertical position in the water column. Parameters that would increase the vertical distribution of fish eggs throughout the water column include decreasing specific gravity and water depth, along with increasing water velocity and turbulence (Garcia et al., 2013; Garcia et al., 2015). Conversely, decreasing velocity as water moves through pools and backwaters would allow particles to settle to the substrate. The MDN gear increases the capability for more complete sampling of the water column for understanding drift and retention processes for fish eggs, larvae, or macro-invertebrates (Matter and Hopwood, 1980; Braaten et al., 2010; Worthington et al., 2013a, 2013b, 2017).

Semi-buoyant fish eggs and larvae are assumed to be randomly distributed throughout the water column as they are transported by river flow to downstream nursery habitats. There is limited data to inform our understanding of reproductive mechanisms and behavior for PBS fish (Worthington et al., 2017). Studies using MECs to infer egg drift (Dudley and Platania, 2007) and retention (Widmer et al., 2010) implicitly assume a normal distribution of passive drifting particles in the water column. The Rio Grande (Braun et al., 2015) and Pecos River (Medley et al., 2007; Worthington et al., 2013a) have complex geomorphology that contribute to egg retention (Widmer et al., 2010; Valdez et al., 2019).
The vertical distribution of particles at upstream and downstream sample points would provide more quantitative data to verify the change in the number of particles from upstream to downstream. The lower number of beads sampled by the MEC compared to the MDN in this study suggest re-evaluation of the drift and retention models may modify interpretation of data from previous studies. The results in Valdez et al., (2019) indicate pre-inundation in-channel spawning in pools and backwaters may limit egg detection and/or transport through heterogeneous river habitat resulting in greater upstream retention of eggs and larvae. Sampling at the water surface may have reduced egg detection capability at steady base flow where sampling with the MDN may increase PBS egg sample size. The lower volume of base flows may produce less turbulence and lower water velocities resulting in eggs distributed lower in the water column. Future studies modeling the environmental conditions and resulting distributions of PBS eggs (specific gravity) will provide valuable information for improving monitoring effectiveness and understanding of egg transport. Parameters that affect the distribution of particles in the water column include egg specific gravity, turbidity, water temperature, water velocity and turbulence. This study illustrates the limitations of two gear types and the use of beads as surrogates for understanding the distribution and transport of PBS eggs in a channel.

\section{ACKNOWLEDGMENTS}

This work was funded in part by the U.S. Army Corps of Engineers' Middle Rio Grande Endangered Species Collaborative Program. The views expressed are those of the author(s) and do not necessarily represent those of the U.S. Army Corps of Engineers. The information being offered herein represents the opinion of the author(s). It has not been formally disseminated by the Bureau of Reclamation. It does not represent and should not be construed to represent Reclamation's determination or policy. Biologists under contract from U.S. Bureau of Reclamation and North Wind Inc. provided logistical support. The authors thank S. Kennedy and K.P. Zehfuss for analyses and early versions of the manuscript, E.M. Zuniga for the drawings. J.S. Aubuchon, A.O. Pinson, D.M. Price, S.P. Schultz, D. Tave, E. Gonzales, J. Lusk, and J. Bachus provided comments that improved the manuscript. P. Dodge at SWCA provided equipment for the photo. We also thank the anonymous reviewers and the Associate Editor for their constructive comments that improved the earlier version of this manuscript. 


\section{DEMONSTRACIJA VIŠESTRUKE NANOSNE MREŽE ZA VODENE ORGANIZME}

\section{SAŽETAK}

Raspodjela kretanja ribljih jaja u rijeci korisna je za razumijevanje ekologije mrijesta pelagičnih riba. Vertikalni raspored jajašaca u vodenom stupcu važan je parametar koji opisuje transportne procese za istraživane vrste. Dizajnirana je mreža s više razina (pet pravokutnih mreža pričvršćenih na okvir) za vertikalno dijeljenje vodenog stupca u vodoravne slojeve za uzorkovanje tekućih uzgonskih čestica. Razmjestili smo višestruku mrežnu opremu za sakupljanje pored Moore-ovih sakupljača jaja u prohodni kanal kako bismo uzorkovali vertikalnu raspodjelu poluzračnih zrnaca poliakrilamidnog gela kao surogate za riblja jaja u vodenom stupcu. Vertikalna raspodjela zrnaca pretežno je pronađena u dubljim mrežama višestrukog zanosnog mrežnog zupčanika, dok su površinske mreže i sakupljači Mooreovih jaja imali manje zrnaca, što je slično s rezultatima drugih istraživanjima mrijesta riba, koji se prenosi pelagijom. Višestruka nanosna mreža je alat koji pokazuje sposobnost uzorkovanja vodenog stupca pod promjenjivim uvjetima protoka (dubina, brzina i turbulencija) za terenske podatke vertikalne raspodje jaja (ili surogata). Ovi empirijski podaci mogu kvantificirati vertikalne obrasce za modeliranje kretanja jajašca pelagijalom pri mrijestu riba.

Ključne riječi: mrijest pelagičnih vrsta, kretanje jajašca, Rio Grande srebrnasta bjelica, Hybognathus amarus

\section{REFERENCES}

Alleman, J. C. (2008): Effects of incubation salinity on egg properties from North American cyprinids. Las Cruces (NM): New Mexico State University. 40 p.

Altenbach, C. S., Dudley, R. K., Platania, S. P. (2000): A new device for collecting drifting semi-buoyant fish eggs. Transactions of the American Fisheries Society, 129, 296-300.

Braaten, P. J., Fuller, D. B., Lott, R. D., Ruggles, M. P., Holm, R. J. (2010): Spatial distribution of drifting Pallid Sturgeon larvae in the Missouri River inferred from two net designs and multiple sampling locations, North American Journal of Fisheries Management, 30,10621074.

Braun, C. L., Pearson, D. K., Porter, M. D., Moring, J. B. (2015): Physical characteristics and fish assemblage composition at site and mesohabitat scales over a range of streamflows in the Middle Rio Grande, New Mexico, winter 2011-12, summer 2012: U.S. Geological Survey Scientific Investigations Report, 2015-5025, 90 p.

Brittain, J. E., Eiklund, T. J. (1988): Invertebrate drift - a review. Hydrobiologia, 166,77-93.
Chase, N. M., Caldwell, C. A., Carleton, S. A., Gould, W. R., Hobbs, J. A. (2015): Movement patterns and dispersal potential of Pecos Bluntnose Shiner (Notropis simus pecosensis) revealed using otolith microchemistry. Canadian Journal of Fisheries and Aquatic Sciences, 72, 1575-1583.

Cowley, D. E., Alleman, J. C., Sallenave, R., McShane, R. R., Shirey, P. D. (2009): Effects of salinity on specific gravity and viability of eggs of a North American minnow (Cyprinidae). Scientia Marina, 73(S1), 47-58.

Dudley, R. K., Barkalow, A. L., Platania, S. P., White, G. C. (2018): Rio Grande Silvery Minnow reproductive monitoring during 2018. Albuquerque, New Mexico: U. S. Bureau of Reclamation. Monitoring report.

Dudley, R. K., Platania, S. P. (1999): Imitating the physical properties of drifting semibuoyant fish (cyprinidae) eggs with artificial eggs. Journal of Freshwater Ecology, 14, 423-430.

Dudley, R. K., Platania, S. P. (2007): Flow regulation and fragmentation imperil pelagic-spawning riverine fishes. Ecological Applications, 17, 2074-2086.

Fluder, J., Porter, M. D., McAlpine, B. (2007): Analyzing floodplain and aquatic nursery habitat of the Rio Grande silvery minnow at different hydrologic flows. In: Nishida, T., Kailola, P. J., Caton, A. E., editors, Third International Symposium GIS/Spatial Analyses in Fishery and Aquatic Sciences: 2005 Aug 22-26, Shanghai, CN. Kawagoe, Fishery-Aquatic GIS Research Group, p. 387-398.

Garcia, T., Jackson, P. R., Murphy, E. A., Valocchi, A. J., Garcia, M. H. (2013): Development of a fluvial egg drift simulator to evaluate the transport and dispersion of Asian carp eggs in rivers. Ecological Modeling, 263, 211-222.

Garcia, T., Murphy, E. A., Jackson, P. R., Garcia, M. H. (2015): Application of the FluEgg model to predict transport of Asian carp eggs in the Saint Joseph River (Great Lakes tributary). Journal of Great Lakes Research, 41, 374386.

Matter, W. J., Hopwood, A. J. (1980): Vertical distribution of invertebrate drift in a large river. Limnology and Oceanography, 25, 1117-1121.

Medley, C. N., Kehmeier, J. W., Myers, O. B., Valdez, R. A. (2007): Simulated transport and retention of pelagic fish eggs during an irrigation release in the Pecos River, New Mexico. Journal of Freshwater Ecology, 22, 499513.

Medley, C. N., Shirey, P. D. (2013): Review and reinterpretation of Rio Grande silvery minnow reproductive ecology using egg biology, life history, hydrology, and geomorphology information. Ecohydrology, 6, 491-505.

Pease, A. A., Davis, J. J., Edwards, M. S., Turner, T. F. (2006): Habitat and resource use by larval and juvenile fishes in an arid-land river (Rio Grande, New Mexico). Freshwater Biology, 51, 475-486. 
Porter, M. D., Massong, T. (2004): Habitat fragmentation and modifications affecting distribution of the Rio Grande silvery minnow. In: Nishida T, Kailola PJ, Hollingworth CE, editors, Second International Symposium GIS/Spatial Analyses in Fishery and Aquatic Sciences: 2002 Sept 3-6, Brighton, UK. Kawagoe, Fishery-Aquatic GIS Research Group, p. 421-432.

R Core Team (2017 June 30): R: A Language and Environment for Statistical Computing 3.4.1.

Reinert, T. R., Will, T. A., Jennings, C. A., Davin, W. T. (2004): Use of egg surrogates to estimate sampling efficiency of Striped Bass eggs in the Savannah River. North American Journal of Fisheries Management, 24, 704-710.

U.S. Geological Survey (1982): Measurement and computation of streamflow. Volume 1. Measurement of stage and discharge. U.S. Geological Survey, Water Supply Paper 2175.

Valdez, R. A., Haggerty, G. M., Richard, K., Klobucar, D. (2019): Managed spring runoff to improve nursery floodplain habitat for endangered Rio Grande silvery minnow. Ecohydrology, 2019, e2134.
Widmer, A. M., Fluder, J. J., Kehmeier, J. W., Medley, C. N., Valdez, R. A. (2010): Drift and retention of pelagic spawning minnow eggs in a regulated river. River Research and Applications, 28, 192-203.

Worthington, T. A., Brewer, S. K., Farless, N. (2013b): Spatial and temporal variation in efficiency of the Moore egg collector. North American Journal of Fisheries Management, 33, 1113-1118.

Worthington, T. A., Brewer, S. K., Grabowski, T. B., Mueller, J. (2013a): Sampling efficiency of the Moore egg collector. North American Journal of Fisheries Management, 33, 79-88.

Worthington, T. A., Echelle, A. A., Perkin, J. S., Mollenhauer, R., Farless, N., Dyer, J. J., Logue, D., Brewer, S. K. (2017): The emblematic minnows of the North American Great Plains: A synthesis of threats and conservation opportunities. Fish and Fisheries, 2017, 1-37. 